\title{
Transformasi Pemikiran Pembaharuan dan Modenisme di Malaysia: Satu Penelitian Awal
}

\author{
Transformation of Renewal Thought and Modernism in Malaysia: \\ a Preliminary Study
}

KAMARUDIN SALLEH ${ }^{1}$

\begin{abstract}
This article is an initial study relating to the thought of renewing and modernism in Malaysia which undergoing the process of transformation since the beginning of the twentieth century till nowadays. This type of thought can be ascertained through the rise of individuals and organizations that uphold such stand, ideas and ideologies. This study basically presents the proper and concise understanding of the concept Islamic modernism such as characteristics, form, nature, development and history. Modernism then, examined specifically in the Malay Archipelago and Malaysia through the political thought of UMNO and PAS that struggle for the Malays and Islam. The results show that both of the political parties tried to accommodate the notion of modernism in practical and real context that influencing much by the political purposes and struggles.
\end{abstract}

Keywords: Islam, Malaysia, modernism, PAS, UMNO

Artikel ini merupakan penelitian awal berhubung dengan transformasi pemikiran pembaharuan dan modenisme di Malaysia yang mendedahkan isu keperluan pembaharuan Islam dan melahirkan golongan dan kumpulan tertentu memperjuangkan fahaman mereka di seluruh dunia Islam. Tulisan ini membentangkan di awalnya pemahaman yang tepat tentang konsep modenisme itu sendiri sama ada menyentuh ciri, bentuk, sifat, perkembangan dan sejarahnya. Kemudian meneliti secara khusus modenisme di Nusantara dan Malaysia secara khususnya menerusi pemikiran politik parti UMNO dan PAS yang memperjuangakan agenda Melayu dan Islam. Hasilnya menunjukkan bahawa kedua-dua parti ini menterjemahkan idea modenisme itu dalam bentuk pemahaman dan tindakan yang berbeza dan dipengaruhi oleh keperluan-keperluan perjuangan politik semasa mereka.

Fenomena kebangkitan Islam sejagat telah melanda dunia Islam dan umatnya sekitar lebih dari dua abad yang lalu. Bertepatan dengan semangat itu juga lahirlah, bermacam-macam seruan dan slogan seumpama al-usuliyyah al-Islamiyyah (Islamic fundamentalism) al-sahwah al-Islamiyyah (Islamic revivalism), al-ihya' al-Islam (Islamic resurgence), al-tajdid dan al-islah (reform, renewal dan reassertion), al-tayyar al-Islami (Islamic current), al-ittijah al-Islami (Islamic tendency), al-ba'th al-Islami (Islamic resurrection), renaissance, regenaration, revitalization, reemergence, resurrection, rebirth, reconstruction, revolution, upsurge, awakening, neo-fundamentalism dan akhirnya Islamism, merupakan terma popular digunakan oleh pembangkit gelombang kesedaran, mengajak

${ }^{1}$ Kamarudin Salleh, Ph.D. Assoc. Prof. at the Department of Theology and Philosophy, Universiti Kebangsaan Malaysia, 43600 Bangi, Selangor, Malaysia. Email: dins@ukm.my. 
masyarakat menyokong arus baru ini. Manakala pada akhir kurun ke 20 dan awal abad 21 kini perkembangan mengarah kepada pemikiran neo-modenisme, liberalisme, postmodenisme, pluralisme dan seumpamanya.

Para orientalis dan sarjana Muslim memakai terma usuliyyun (fundamentalist) dan Islamiyyun (Islamist) kepada golongan yang mempunyai kecenderungan dan nada politik dalam perjuangan mereka (Haddad 1986 dan Dessouki 1982). Sifat khusus ini selalunya untuk membezakan dengan gerakan kebangkitan atau kesedaran Islam seperti neotradisionalisme yang tidak bersifat politikal (apolitical). Umumnya, seruan kesedaran dan kebangkitan Islam ini berobjektif utama untuk menyedarkan kembali umat Islam, memandangkan situasi dan kondisi semasa mereka, rata-ratanya yang disifatkan berada dalam keadaan serba-serbi inferior dan subordinate bertembung dengan program dan aksi kolonalis-imperialis Barat. Kemelut sarjana Muslim pula ialah mencari formula penyelesai ampuh dan mantap bagi masalah dalaman umat Islam dan sekaligus juga memberi tindakbalas secara efektif rempuhan dan cabaran hebat tamadun Barat moden (Alatas 1972). Ini tercermin dalam kepelbagaian sikap dan aliran pemikiran bertembung dengan gugatan dan cabaran tersebut; antara ekstrim (terlampau) lebih (ifrat, al-ghuluw) dan ekstrim (terlampau) kurang (tafrit): "a continumm stretching from extreme conservatism to extreme westernism" (Sidek Fadzil 1989). Berdepan situasi ini, umat Islam dan Islam berusaha mencari identiti asalnya ${ }^{2}$ yang secara otomatik, tidak lain dan tidak bukan, mesti kembali kepada sumber aslinya untuk mencapai tahap keagungan dahulu seperti Zaman Kegemilangan dan Keunggulannya (Golden Era of Islam). Ekoran itu muncul ramai tokohtokoh pembaharuan, pemikir tajdid, islah dan organisasi dari berbagai-bagai negara, latarbelakang, aliran dan metodologi.

Observasi awal terhadap reaksi dan tindakbalas yang dikemukakan oleh intelektual Muslim menempuhi cabaran pemodenan dan pembaratan dalam berbagai-bagai bidang meliputi politik, ekonomi, kemasyarakatan dan keagamaan mewujudkan tiga atau empat kelompok dan aliran pemikiran utama; tradisionalisme-konservatisme, fundamentalisme, reformisme-modenisme, sekularisme-liberalisme (tradisionalis, revivalis dan rasionalis). Pengelompokan ini adalah bersifat umum dan garis besar sahaja, di mana masih banyak aliran dan kumpulan kecil atau pecahan lain seperti neo-tradisionalisme, neo-modenisme dan seumpamanya. Ciri-ciri setiap kumpulan tidaklah eksklusif atau tersendiri bahkan dalam sesetengah keadaan adalah bertindih. Dengan nama lainnya pula yang boleh dirujuk dari karya karya dan tulisan berbahasa Arab terdapat kumpulan yang digelar sebagai sekolah atau aliran: madrasah al-ra'yu, madrasah al-athar, madrasah muwazanah wa tarjih bayn madrasah al-ra'yu wa al-athar dan madrasah asalah al-fikriyyah fi syari'atina wa tasyri'atina (Mohd. Rumaizuddin 2005).

Aliran pemikiran di atas boleh digolongkan sebagai cenderung kepada rasionalis atau modenis, tradisionalis atau konservatif, neo-modenis dan fundamentalis. Sarjana yang cuba terlalu mempermudahkan pengelompokan dan pengkategorian tersebut hanya menyebut dua kumpulan; modenis (Barat) dan fundamentalis (tradisional) seperti pandangan Akhbar S. Ahmed di bawah:

Western Orientalists perceive in Muslim scholarship and their society two distinct, contradictory and exclusive alternatives - 'Westernized modernists' or 'traditional fundamentalists' - a lead followed somewhat uncritically by

2 "After all, for the Muslim World, the quest for independence from Western subjugation was, in most instances, closely connected with the Muslim search for 'identity', and a certain disillusionment with Western values and worldview", lihat Hussin Mutalib. 1993. Islam in Malaysia: from Revivalism to Islamic State. Singapore: Singapore University Press. 
Muslim scholars themselves. The former are seen as 'liberal', 'humanist', 'progressive', and by implication the 'good guys'. The latter are 'fanatic', 'retrogressive', and the 'bad guys'. The application of these Western labels best suited for political analysis in Western democracies could be misleading in the Muslim world (Akhbar 1988: 200).

Pernyataan ini mewakili persepsi Orientalis dan masyarakat Barat yang cenderung melabelkan kumpulan dan gerakan Islam dengan kata sifat tertentu. Malangnya, secara sedar atau tidak, ramai juga sarjana Muslim sendiri menerima pakai pengkategorian di atas dan menulisnya dalam karya-karya atau tulisan-tulisan mereka. Hakikatnya, kemunculan kumpulan dan pertubuhan ini, hendaklah dikaji selidik dan difahami sebagai satu rantaian kesinambungan dan rangkaian sejarah perkembangan pemikiran masyarakat Islam, apabila bertembung dengan perubahan persekitarannya sama ada berbentuk dalaman (endogenous) dan luaran (exogenous) atau kedua-duanya sekaligus. Perlu diingati bahawa memang timbul masalah dengan pengkategorian ini, ramai ulama tidak setuju atau kurang setuju bahkan menolaknya. Al-Qaradawi menyatakan keselesaannya memakai kalimah kebangkitan Islam daripada kalimah-kalimah seperti fundamentalisme kerana beliau berkeyakinan yang harus menjadi pertimbangan adalah apa yang ada di sebalik nama dan kandungannya bukan terletak pada nama dan judulnya. Muhammad Imarah mengakui, umat Islam turut memakai terminologi-terminologi yang merugikan mereka dari Barat. Maka, menjadi kewajipan semua untuk membebaskan terma-terma menyeleweng kepada makna sebenar sehingga menyelamatkan pemikiran Islam dari bahaya yang ditimbulkan. Muhammad Natsir menyarankan istilah yang datang dari Barat perlu ditinjau penggunaannya dan diletakkan pada tempat yang betul apabila dikaitkan dengan Islam dan pertubuhan seperti Hizbut-Tahrir memang menolak pemakaian terma dan istilah di atas yang seolah-olah dipaksakan ke atas umat Islam. Konklusinya penggunaan istilah dan label sebegini bukanlah sesuatu perkara asas yang boleh menjadikan umat Islam bertengkar sesama sendiri kerana pihak musuh Islam mahukan perkara itu berlaku dan penting istilah tersebut diberi tafsiran selaras dengan acuan dan pendirian kita.

Menghurai transformasi pemikiran pembaharuan modenisme progresif dan modenisme umum yang menjadi fokus tulisan ini, awal-awal lagi diperingatkan bahawa terma ini merupakan salah satu daripada terma kabur dan abstrak untuk didefinisikan, sekalipun aliran ini antara yang utama dan besar dalam pemikiran Islam. Kelahiran corak pemikiran modenisme dapat ditelusuri sekitar akhir kurun ke 19 Masihi, mengambil inspirasi daripada pemikiran rasionalis golongan Muktazilah. Perkembangan pemikiran modenisme, sebagai respon kemudiannya memunculkan fundamentalisme yang kritikal dan kontradik dalam banyak perkara dengan modenisme. Penulis-penulis mutakhir seperti Maryam Jameelah, Uthman El-Muhammady, Wan Muahammad Ali dan Abd al-Qadir al-Sufi menggunakan istilah modenisme ini dengan perasaan penuh curiga dan menuduh kalangan modenis ingin membarat (menjadikan Barat) dan mensekularkan Islam (Wan Muhammad Ali dan Muhammad Uthman El-Muhammady 1977). Pendekatan atau metodologi fundamentalisme ini walau bagaimanapun mendapat sokongan hebat masyarakat kelas pertengahan dan mendakwa mewakili penganut Islam yang masih setia kepada ajaran agama dan mempertahankan Islam sebagai suatu cara hidup (syumul) (Mohamad 1994).

\section{Permasalahan}

Tema transformasi ke arah kebangkitan dan pembaharuan telah dibicarakan secara ekstensif dari beberapa sudut oleh ramai ahli akademik; baik dalam mahu pun luar negara, 
Muslim dan non-Muslim. Kajian ini menjuruskan perbahasan kepada isu atau persoalan modenisme-progresif dalam pemikiran (politik) Islam di Malaysia pada dekad-dekad akhir abad 20 lalu; berkait dan fokus kepada tabii atau sifat-sifat pokok, perkembangan, dan impak pemikiran modenis Muslim tersebut. Di mana arah wacananya merujuk kepada parti UMNO dan PAS yang merupakan dua parti politik Melayu utama dan berterusan bersaing mahu menjuarai perjuangan agama dan politik Malaysia. Pandangan beberapa tokoh akademik, pemikir dan ulama yang diklasifikasikan sebagai modenis akan diterokai menyentuh kedudukan Islam dan politik di Malaysia. Kalangan ini mewakili individu, ahli akademik dan parti-parti politik dominan Malaysia.

Penyelidik membuat penelitian, kajian dan mengenalpasti bentuk dan corak pemikiran modenisme progresif Malaysia atau ala-Malaysia (manhaj Maliziyy). Satu bentuk transformasi pemikiran pembaharuan dan modenisme yang sesuai dengan dunia Melayu Malaysia atau mengambil kira aspek kontekstual dan pribumisasi Melayu. Penulis menyedari kesukaran yang timbul menyentuh terma itu sendiri namun usaha dilakukan untuk meletakkan konsep modenisme kepada sebuah "model" penafsiran dan "kerangka pemahaman" yang bersifat praktis dan bukannya suatu pernyataan yang bersifat objektifmutlak tentang sifat-sifat pokok (nature) dari pembaharuan umum di dunia dan di sekitar kita semata-mata, disebabkan keperluan-keperluan penganalisisan. Oleh kerana itu, konsekuensinya, "kerangka pemahaman" dan penafsiran tersebut bukannya merupakan suatu pendapat yang bersifat "tetap" atau tidak berubah-ubah melainkan sekadar frame pendekatan untuk menjelaskan hakikat pokok dan utama sesuatu itu. Jadi, aliran dan pemikiran modenisme Malaysia pada tahap tertentu berbeza dengan konsep asalnya sama ada gagasan dan anjuran Ahmad Khan, al-Afghani dan Abduh, khususnya merujuk kepada perkembangan pada lewat kurun ke 20 ini, yang mana sekaligus mencerminkan perubahan, perbezaan pemikiran dan pendekatan kerana merai dan terpengaruh dengan realiti masyarakat, lokaliti dan persekitarannya. Contohnya pemikiran modenis dirumuskan kepada beberapa konsep utama seperti; penekanan kepada rasionaliti dan kebebasan manusia, mengharmonikan kepercayaan Islam dengan nilai-nilai moden di atas sikap $a$ priori bahawa pandangan dunia Islam selari dengan pandangan dunia Barat, tetap terbukanya pintu ijtihad dan sebagainya. Manakala berkaitan pemikiran politik modenis, terdapat tiga perkara utama; supremasi undang-undang, pemisahan agama dari urusan politik, dan praktikalitinya. Mengambil kes pandangan pemisahan agama dan urusan politik, nyata sekali aliran modenisme di Malaysia tiga dekad kebelakangan ini berbeza dan tidak dapat menerima anjuran ini. Ekoran itu, konsep modenisme Malaysia memerlukan pengubahsuaian pentakrifan dan penciriannya tersendiri, tercerna dalam realiti tempatan, contohnya dalam kes perkongsian kuasa (power sharing) yang diamalkan oleh parti-parti politik sama ada UMNO mahu pun PAS di Malaysia sewaktu mentadbir negara mahu pun negeri yang diperintah oleh UMNO (Barisan Nasional) atau PAS (Pakatan Rakyat).

Kajian ini bertolak dari pembentangan sepintas lalu senario perkembangan dan proses perubahan bentuk dan corak pemikiran Islam di dunia Islam. Fazlur Rahman, tokoh tersohor kontemporari meneliti kelahiran gerakan-gerakan pembaharuan Islam secara umum dan bentuk-bentuk asasnya. Meringkaskan penelitiannya, sejarah gerakan pembaharuan Islam selama dua abad terakhir ini dibahagikan kepada empat bentuk; pertamanya, gerakan revivalis di akhir abad ke-18 dan awal abad ke 19 yang merangkumi, sebagai misalannya gerakan Wahhabiyyah di Arab Saudi, gerakan Sanusiyyah di Afrika Utara, gerakan Fulaniyyah di Afrika Barat dan peperangan Paderi di Indonesia. Keduanya, gerakan modenis, sebagai fokus kajian yang dipelopori di India oleh Sayyid Ahmad Khan, Jamal al-Din al-Afghani di India, Turki dan Timur Tengah serta Muhammad Abduh di Mesir. Ketiganya, neo-revivalisme (neo-fundamentalisme) yang moden dan bersifat agak 
reaksioner, di mana al-Maududi berserta kelompok Jamaat-i-Islaminya di Pakistan merupakan contoh terbaik bagi kumpulan ini menurut Fazlur Rahman dan, keempatnya, neo-modenisme yang beliau sendiri meletakkan dirinya dalam kumpulan terakhir ini dengan alasan kerana neo-modenisme mempunyai sintesis progresif dari rasional modenis dengan ijtihad dan tradisi klasik dan beliau lebih jauh lagi menganggap neo-modenisme sebagai pra syarat utama bagi Renaissance Islam (Barton 1999: 9).

Dalam konteks Malaysia, benih-benih kebangkitan semula dan bibit-bibit perkembangan pemikiran dan aliran modenisme (ada yang menyatakan reformisme) ini, dapat direkodkan tarikh paling awal dan jelas (Abu Bakar 1991) disandarkan kepada penerbitan majalah berkala Al-Imam pada tahun 1906-1908. Majalah yang diusahakan oleh sekumpulan intelektual-ulama pembaharu Muslim berpusat di Singapura; terdiri dari Syeikh Muhammad Salim Al-Kalali, Syeikh Muhammad bin Aqil, Haji Abbas bin Muhammad Taha (1885-1945), Sayyid Syeikh al-Hadi (1867-1934), dan Syeikh Muhammad Tahir bin Jalaluddin al-Azhari (1869-1957). Kelompok ini dipanggil Kaum Muda, sinonim modenis atau golongan yang berfahaman modenis (reformis) dan progresif berbeza dengan Kaum Tua atau Lama, identikal dengan tradisionalis-konservatif. Terma Kaum Muda dan Tua tidak dapat dipastikan dengan tepat bila dan siapa mula-mula memakainya. Namun begitu dalam majalah Al-Ikhwan yang diterbitkan pada bulan Mac tahun 1929 ada satu artikelnya yang jelas menyebutkan penggolongan Kaum Muda dan Tua dengan tajuk Perchayaan Ulama: Pertengkaran Di Antara Kaum Tua dan Kaum Muda. Tulisan-tulisan Ginsburg dan Roberts, Radin Soenarno, V. Thompson, R.J.H. Sidney, dan H.M. Federspiel membincangkan secara mendalam kedua-dua kumpulan ini (Federspiel 1970)3. Menurut Roff, terma Kaum Muda dan Tua ini mempunyai makna yang berbagai-bagai sebagaimana yang digunakan oleh orang Melayu di Malaya dan beliau menyatakan kesilapan dan salah faham pada pandangan Thompson dan Sidney menyentuh isu ini kerana pentakrifan yang tidak tepat dan terpengaruh dengan terma Barat serta cuba mengaitkan kegiatan mereka dengan organisasi politik. Namun Roff tidak menggunakan terma Kaum Muda dengan maksud khusus kepada modenis tetapi lebih umum kepada reformis Islam dan jelas bagi beliau gerakan modenis (reformis) Kaum Muda di Tanah Melayu tidak pernah berjaya membawa kepada sokongan massa yang hebat ke arah menyemarakkan protes sosial atau politik:

It never succeeded, for example, in creating a mass movement similar to either non-political Muhammadiyah or the activist Sharikat Islam in Indonesia, in spite of much discussion of the need for unity and association, and it seems never to have created real anxiety on part of the British (Roff 1962: 175).

Mohd Sarim Mustajab (1979) menyatakan, penyelidikan yang dijalankan tentang "Gerakan Islah Islamiyah" (reform) di Tanah Melayu setakat ini nampak sepakat mencapai satu premis bahawa gerakan Islah itu terus menjadi malap dan kehilangan fungsinya menjelang tahun 1930an. Suasana ini berlaku kerana wujudnya perkembangan baru pada tahun-tahun 1930an seperti soal kemasukan bangsa asing dan kedudukan orang Melayu makin terhimpit oleh kegiatan bangsa asing dalam negeri mereka sendiri. Isu ini lebih hangat diperkatakan pada era selepas 1930an. Kemudian muncul golongan elit Melayu berpendidikan sekular yang mengambil alih peranan menggerakkan semangat

${ }^{3}$ Federspiel membincangkan polemik Kaum Muda dan Tua pada bab empat tulisannya; bangkangan Kaum Muda terhadap Kaum Tua kerana penekanan kepada amalan tasawuf, kerigidan dalam amalan mazhab, pengamalan bidaah, penggunaan akal yang kurang dan tidak rasional, ijtihad dan taklid buta dan beberapa isu kecil lain seperti khutbah, talqin, niyyah dan lain-lain. 
nasionalisme orang Melayu dan diikuti dengan penubuhan parti-parti politik nasionalissekular sebagai agenda utama (Mohd Sarim 1979).

Realiti perkembangan pembaharuan di Tanah Melayu pada awal abad lalu, membuktikan ia tidak mampu mencetuskan satu organisasi politik berteraskan Islam sebagaimana yang pernah berlaku di Indonesia. Roff menambah modenis (reformis) Malaya tidak berjaya mewujudkan pertubuhan atau organisasi dakwah, sosial atau politik seperti rakan-rakan mereka di Indonesia: "unlike the Indonesian movement, it never succeeded in elaborating, either organizationally or programmatically, a political nationalism capable of attracting mass support" (Roff 1967: 87). Namun premis ini pun ada kelonggaran faktanya menurut Mohd Sarim; Pertama, penyelidikan tersebut tidak membataskan tahap waktu perbicangan memperkatakan tentang gerakan Islah. Kedua, kelonggaran ini wujud mungkin disebabkan gerakan Islah itu sendiri dilihat sebagai satu episod dan tempat bertolak dalam satu gerakan nasionalisme Melayu yang dipelopori oleh golongan elit sekular. Oleh kerana itu, peranan Islam sebagai penggerak kepada gerakan politik orang-orang Melayu seolaholah dimatikan setakat tahun 1930an sahaja. Selepas itu dikatakan trendnya sedikit berubah kepada mewujudkan organisasi sosial seperti Persaudaraan Sahabat Pena Melayu yang kepimpinannya datang dari keturunan Arab-Islam. Selanjutnya, ketiga, beliau cuba berhujah bahawa berdasarkan fakta sejarah kebelakangan ini, gerakan Islah yang muncul di tahun-tahun awal abad dahulu tidak seharusnya dilihat sebagai satu episod kecil dalam keseluruhan proses munculnya semangat nasionalisme Melayu. Tetapi mesti dipandang sebagai satu aspek kemunculan semangat perjuangan Melayu berlandaskan Islam. Pemikiran bercirikan modenisme ini seperti yang diutarakan di atas, kemudiannya diperhatikan tahap perkembangan adalah malap, lembap dan sambutannya dingin serta didapati fahaman ini hanya didokongi oleh individu-individu tertentu secara selektif, elit, tidak ramai, kurang mantap dan tidak berakar umbi menjadi satu institusi atau aliran dominan dalam masyarakat. Satu pertanyaan timbul, mengapakah wujudnya kelompangan dalam perkembangan pengikut dan pemikiran modenisme di Malaysia pada zaman-zaman selepasnya. Tidak seperti di Indonesia, mengambil pandangan sarjana Faisal Othman yang katanya mempunyai dua tradisi seimbang di antara Pertubuhan Muhammadiyyah yang bersifat progresif-modenis manakala Nahdatul Ulama yang lebih bersifat tradisionaliskonservatif. Di Malaysia, tambahnya lagi, tidak wujud dua tradisi pemikiran begini, jadi kalangan mereka yang berpemikiran modenisme kurang mendapat tempat, tersisih dalam masyarakat disebabkan majoriti masyarakat adalah cenderung kepada aliran tradisionalisme-konservatisme-fundamentalisme (Faisal 2002).

Bertolak dari hakikat keterasingan fahaman modenisme dalam penerimaan majoriti masyarakat tadi, penyelidik berusaha memeriksa kecenderungan sifat dan bentuk modenis (setelah ditakrif dan diberikan kriteria sendiri) dalam pemikiran tokoh-tokoh tertentu sama ada dari kalangan intelektual, ulama dan politikus Malaysia semasa, berkait dengan beberapa isu seperti Islam dan politik atau permasalahan negara Islam: meliputi kefahaman negara Islam, kriteria umum, struktur negara Islam dan perancangan mendirikan negara Islam dan konsep nasionalisme (negara bangsa) di Malaysia.

Kajian ini berobjektifkan menelusuri transformasi pemikiran pembaharuan dan modenisme dalam urutan dan rantaian perkembangannya berhubung langsung dengan pasca-modenisme dan globalisasi kontemporari. Matlamat umumnya berusaha menganalisis persoalan modenisme dalam konteks Malaysia yang diyakini mempunyai unsur-unsur indigenization atau pemeribumian tempatan akan idea-idea universalnya; memaparkan rantaian persejarahan kemunculan dan perkembangan modenisme di Nusantara-Malaysia, mengemukakan perspektif konsep modenisme dan sifatnya di Malaysia secara khusus berdasarkan realiti masyarakat Islam Malaysia, menganalisis 
pandangan dan pendapat tokoh-tokoh modenis Malaysia menyentuh beberapa isu pilihan politik dalam konteks Malaysia seperti idea negara Islam dan nasionalisme (nation-state), dan menganalisis pemikiran modenis dalam parti politik UMNO dan PAS berhubung isu modenisme dan impaknya di Malaysia.

\section{Skop Kajian}

Kajian mewacanakan permasalahan modenisme merangkumi aspek terminologi, genealogi, sejarah kelahiran, perkembangan, ciri dan kriteria, hubungan modenisme Islam dan Barat. Pengkaji menerima pakai dan merujuk kepada tarikh akhir kurun ke 19 Masihi sebagai titik kelahiran modenisme sebenar yang mempunyai ciri dan sifat khusus berbeza dalam beberapa hal dengan revivalisme pra-moden atau modenisme klasik. Pembahagian dan istilah yang digunapakai Fazlur Rahman kepada gerakan revivalisme Wahhabiyyah, Sanusiyyah dan lain-lain lagi yang berlaku pada kurun ke 18 Masihi adalah tidak sama dengan penelitian ini yang mana tokoh-tokoh pelopor modenis tersohor dirujuk kepada Afghani, Abduh dan Iqbal.

Kajian selanjutnya berusaha mendefinisikan modenisme dalam konteks Malaysia dan menyelidiki rantaian persejarahan dan transisi serta transformasi pemikiran modenisme di Malaysia yang menerima impak gerakan-gerakan pemodenan luar sama ada secara langsung atau tidak langsung. Tokoh-tokoh modenis awal Malaysia seperti al-Hadi dan Tahir Jalaluddin akan dijadikan tempat bertolak kemunculan benih-benih modenisme dan berkembang aliran pemikiran modenis pada zaman-zaman selepasnya. Nyatanya aliran modenisme tidak mendapat sambutan meluas dari kalangan masyarakat awam dan pemerintah yang rata-ratanya mirip tradisionalisme-konservatisme. Jadi, faktor-faktor atau halangan-halangan yang menyebabkan berlaku keadaan sedemikian akan diperhalusi, kerana pada masa ini pun pemikiran yang bersifat modenis ini dicurigai dan dianggap sekular atau kebaratan (Abd. al-Qadir al-Sufi 1979: 4-5) ${ }^{4}$ sehinggalah ia terus-menerus tidak mendapat sokongan dan kedudukan dalam masyarakat awam. Walaupun tidak dinafikan, ada kalangan tertentu secara individu ataupun kolektif dalam satu-satu pertubuhan dan parti berfahaman modenisme. Dalam konteks inipun modenisme yang bersifat ala Malaysia perlu dicerakinkan dan diperkemaskan pentakrifannya supaya berbeza pencirian kecilnya dengan idea-idea tokoh-tokoh modenis luar negara. Perlu disebutkan juga bahawa dari sudut pemikiran wujud kriteria yang berbeza di antara revivalis dengan modenis kerana tidak semestinya kalangan revivalis itu berpemikiran modenis, bahkan yang majoritinya adalah berfahaman fundamentalis (neo-fundamentalis) dan tradisionalis. Perbincangan selanjutnya, menelaah aspek pemikiran politik tokoh yang dikriteriakan modenis di Malaysia dengan menyingkap pandangan dan idea mereka berkenaan konsep negara Islam dan nasionalisme; sama ada tokoh-tokoh itu dari ahli politik dan bukan politik seperti UMNO dan PAS.

Jelasnya, kajian ini membataskan perbincangan kepada modenisme di Malaysia pada beberapa tahap masa mutakhir, menyentuh isu-isu pemikiran politik tertentu oleh pertubuhan atau parti politik tertentu. Wajar disebutkan, kajian ini tidak meneroka secara detil idea-idea modenisme yang dikemukakan oleh tokoh-tokoh reformis-modenis tahun 30 an seperti al-Hadi dan Tahir Jalaluddin dalam bidang pendidikan, kewanitaan, politik dan keagamaan, walaupun urutan perkembangan modenisme tersebut akan dibincangkan

4 Yusril Ihza Mahendra menyebutkan bahawa terdapat kalangan yang mendakwa Afghani, Abduh dan Ahmad Khan sebagai agen imperialis serta tokoh-tokoh pelopor modenisme itu alat agen "Freemasonry". Dan mereka ini sengaja diperalat oleh organisasi rahsia kaum Yahudi itu untuk "merosakkan Islam" dan melemahkan kaum Muslim dari dalam. 
(Ibrahim 1994). Penelitian tidak meneroka secara khusus pemaparan asas-asas falsafah umum pemikiran modenisme ataupun pemikiran reformis moden berkaitan dengan dasardasar intelektual, politik, ekonomi, sosial dan pendidikan yang mendominasi pemikiran modenis Islam keseluruhannya, tetapi menjuruskan kepada rantaian persejarahan, perkembangan, tabii dan impak modenisme serta beberapa aspek pemikiran politik dalam konteks Malaysia.

Kajian ini penting dan relevan dalam menganalisis perkembangan, tabii dan impak aliran modenisme di Malaysia. Pertamanya, betapa pun telah ada usaha dilakukan untuk memahami modenisme pada tahun-tahun 30 an dahulu tetapi dalam dekad-dekad mutakhir ini, belum ada penyelidikan khusus mengenainya. Keduanya, pendekatan dan perspektif yang diambil berbeza dari kajian-kajian lepas, tesis ini terlebih dahulu memperhalusi dan memperkemaskan karakteristik atau ciri-ciri pokok modenisme; bermula dengan dasardasar umum (di dunia Islam umumnya) dan diperincikan lagi elemen-elemen khusus dalam realiti Malaysia. Setelah itu, barulah analisis menjurus kepada aspek-aspek tertentu perbincangan dalam pemikiran politik Islam seperti kedudukan atau konsep negara Islam, nasionalisme dan lain-lain lagi. Ketiganya, mengenalpasti posisi dan pendirian gerakan Islam dan parti politik seumpama UMNO dan PAS berdepan dengan isu-isu politik Islam semasa serta hujah-hujah pegangan mereka. Keempatnya, menjelaskan kemalapan dan kegagalan semangat modenisme Islam Malaysia membentuk satu aliran kuat dan seimbang (pendesak) dengan tradisionalis-fundamentalis sehingga dapat memberikan ruang bernafas kepada pendekatan moden Islam dan sekaligus mengelakkan daripada dilihat lebih cenderung kepada dominasi jumud, kolot, ekstrim dan fanatik yang diperjuangkan oleh fundamentalis dalam idea dan amalan mereka. Kajian juga diharap dapat memberi rumusan probabiliti masa depan fahaman modenisme di Malaysia, berdasarkan realiti yang berlaku ke atas penyokong dan aliran ini sekarang.

\section{Metodologi Kajian}

Kajian secara dasarnya lebih bersifat kajian perpustakaan dengan pendekatan kualitatif yang diperkemas dan dibantu oleh data-data temubual dan pemerhatian. Pendekatan kajian bersifat analisis deskriptif dan penghuraian atau interpretasi kritikal, terutama sekali dalam pemeriksaan fakta-fakta yang ada hubungan dengan permasalahan pokok kajian; konsep modenisme, modenisme ala Malaysia dan impaknya. Kajian perpustakaan dilaksanakan untuk merumuskan kerangka teoritikal dan 'framework' kepada idea modenisme. Sejarah dan perbandingan perkembangan gerakan pembaharuan turut dimasukkan. Jadi rujukan perpustakaan yang ekstensif dijalankan bagi mendapatkan bahan atau sumber literatur komprehensif mengenai tajuk dan diikuti dengan pendokumentasian bahan-bahan sekunder tersebut secara teratur dan kemas. Pendekatan kualitatif digunakan kerana fokus penyelidikan menitikberatkan pada kajian konseptual yang bersifat penganalisisan pemikiran dan bagaimana pemikiran itu tersosialisasi. Berasaskan kaedah ini, pengkaji mengkategorikan dua bentuk sumber asas bahan analisis kajian iaitu bahan primer dan bahan sekunder.

Sumber primer diperolehi melalui proses temubual formal dan tidak formal. Temubual formal bersifat temujanji khas yang telah ditetapkan antara pengkaji dan sarjana terpilih. Manakala interbiu tidak formal, berlaku semasa pengkaji hadir di dalam satu-satu seminar, wacana dan simposium ataupun sewaktu di meja makan, di mana pengkaji bertanya tentang isu-isu yang dikaji. Pengkaji juga melakukan pemerhatian langsung kepada perkembangan pemikiran pembaharuan di Malaysia kini dan cuba memadankan kerangka teori dengan kriteria perkembangan tersebut. Oleh kerana pengkelasan individu 
dan gerakan dibuat berdasarkan penilaian pengkaji maka takrifan terma modenisme (reformisme) dalam konteks Malaysia perlulah diselarikan suasana dan kejadian lokal. Penyelidikan perpustakaan yang bersifat sekunder selanjutnya melengkapi data-data primer tadi dan data ini memang banyak ditulis kerana isu yang diwacanakan bersifat pemikiran politik serta kontemporari.

Beralih kepada bagaimana bahan-bahan dan maklumat-maklumat yang diperolehi akan dibincang dan dianalisis, terdapat beberapa kaedah dan pendekatan digunapakai untuk memenuhi kriteria sebuah tesis yang baik. Kaedah penganalisisan induktif dan deduktif akan digunakan yang merangkumi, pertamanya analisis persejarahan umum modenisme. Di mana pengkaji secara langsung mendiskusi permulaan kemunculan modenisme Barat dan perkembangannya yang memberi kesan nyata kepada kelahiran pemikiran modenisme Islam seumpama yang diasaskan al-Afghani dan Abduh. Dari kerangka konsep modenisme tokoh-tokoh inilah akan diteliti pula bagaimana kemunculan di alam Nusantara serta diikatkan dengan perbincangan pemikiran politik Islam Malaysia semasa. Keduanya, bersifat analisis ulasan dan kritikan, di mana penulisan menilai secara kritikal dan mengulas pendapat dan idea yang dikemukakan dalam konteks pemikiran Islam dan pemikiran politiknya dan meletakkannya sesuai dengan realiti politik dunia Islam dan Malaysia. Ketiganya, analisis interbiu dan pemerhatian yang didapati dari kajian lapangan sebagai sumber primer pengukuhan pandangan sarjana Muslim Malaysia menyentuh isu nasionalisme dan negara Islam. Akhir sekali, analisis perbandingan pandangan antara gerakan Islam di Malaysia dan juga perkembangan isu tersebut di negara-negara Islam lainnya yang akan dijadikan diskusi perbandingan.

Perlu disebutkan juga bahawa kajian ini tidak menggunakan kaedah persampelan soal-selidik kerana pengkaji berpendapat kaedah itu tidak sesuai atau relevan. Alasannya ialah tahap pengetahuan dan kefahaman masyarakat awam terhadap konsep negara dan pemerintahan mahu pun nasionalisme tidak memungkinkan mereka membuat komen dan analisis bernas, berdasarkan perkara ini adalah perbincangan kalangan intelektualakademis.

\section{Sorotan Kajian Lepas}

Persoalan modenisme (sama dengan fundamentalisme) seperti yang disebutkan lebih awal adalah merupakan satu bidang yang sangat luas dan banyak aspek-aspeknya sudah dikaji, dibahas dan ditulis sama ada menurut perspektif sarjana Muslim maupun bukan Muslim. Perbincangan tersebut ada yang bersifat idea-idea umum kumpulan ini, individu dan pertubuhan yang diidentifikasikan mempunyai kecenderungan seperti itu dan kadangkadang bersifat kajian kes di negara-negara tertentu seperti Mesir, Palestin, Sudan, Indonesia dan lain-lainnya. Dalam konteks Malaysia modenisme adalah berkait rapat dengan reformisme atau revivalisme, walaupun bukanlah setiap reformisme itu modenisme. Menyentuh literatur terdahulu bagi kajian ini, paling tidak boleh dibahagikan kepada 3 penekanan aspek kajian berbeza telah dibuat. Pertamanya, buku-buku dan tulisan-tulisan yang berkaitan dengan persoalan modenisme secara umum seperti Mazheruddin Siddiqi (1982). Buku ini menganalisis pemikiran tokoh-tokoh besar modenis Islam terhadap persoalan-persoalan utama dunia Islam iaitu; intelektual, politik, ekonomi, sosial dan pendidikan. Ringkasnya tokoh-tokoh modenis ini menghujahkan bahawa pentafsiran bercorak tradisional sudah tidak dapat memuaskan hati ramai orang yang menerima pendidikan moden. Memang ada sebahagian dari pemikir-pemikir moden tersebut agak ekstrim sehingga seolah-olah memisahkan semua urusan keduniaan dari asas Islam. Namun ada yang tidak ekstrem tetapi masih tidak percaya bahawa perundangan 
(fiqh) di Abad Pertengahan boleh memenuhi kehendak-kehendak moden. Umumnya golongan modenis ini percaya kepada kehebatan akal (sovereignty of reason) dan menolak mana-mana pandangan dan pegangan yang tidak lulus ujian akal. Dalam buku ini dipetik pandangan tokoh-toloh modenis seperti al-Afghani, Abduh, Syed Ahmad Khan, Rashid Ridha, Iqbal dan lain-lain lagi menyentuh berbagai-bagai persoalan modenisme.

Buku seterusnya tulisan Charles C. Adams (1968) yang membahaskan secara khusus pemikiran tokoh-tokoh modenis Mesir terutamanya Syeikh Muhammad Abduh dari berbagai-bagai sudut, dengan penekanan kepada reformasi yang perlu dilakukan oleh orang-orang Mesir dalam bidang pendidikan, teologi, undang-undang dan politik. Membentangkan secara tidak langsung pemikiran dan karakteristik modenisme Islam yang berusaha untuk mendekatkan (taqrib), mengharmoni dan membina jambatan disebabkan perbezaan antara idealisme Islam, normatif Islam dan perkembangan sejarah komuniti Muslim (historical Islam and Muslim). Lantaran itu, pentafsiran Abduh banyak merujuk kepada keselarasan antara Islam dan sains atau wahyu dan akal bagi membuktikan kesejagatan (universalism) Islam.

Kategori keduanya buku-buku dan tulisan yang berkaitan dengan kajian Islam dan modenisme di Asia Tenggara, terutamanya Malaysia didapati agak banyak dilakukan oleh pengkaji luar dan dalam; antara sarjana luar seperti Barraclugh (1980), Miller (1980), Kessler (1978, 1974 \& 1972), Means (1991, 1982 \& 1978), Von Der Mehden (1988, 1987, 1986a, 1986b \& 1980), Milner dan Mauzy (1986, 1983-84 \& 1980), Nagata (1984, 1980a \& 1980b) dan Nash (1991, 1984 \& 1978). Manakala tokoh-tokoh tempatan Chandra Muzaffar (1996, 1987 \& 1986), Hussin Mutallib (1996, 1994, 1993, 1990a \& 1990b), Mohamed Abu Bakar (1994, 1991, 1986 \& 1981) dan Muhammad Syukri Salleh (1994a \& 1994b). Secara khusus, Ibrahim Abu Bakar (1994) menghuraikan secara jelas perbincangan modenisme Islam di Malaya sebagaimana dikemukakan oleh al-Hadi; meliputi aspek-aspek ritual, pendidikan, wanita dan politik dalam Islam. Secara ringkas, penulis mengemukakan garis kasar pemikiran modenisme Islam pada bab awalnya menurut perspektif al-Afghani, Abduh dan Ahmad Khan. Tokoh-tokoh ini melihat banyak masalah yang dihadapi oleh masyarakat Muslim dalam hidup mereka seperti pendidikan, akal, sains, agama, sufi dan politik.

Safie Ibrahim (1987) dalam disertasinya memfokuskan perbincangan kepada pemikiran keagamaan Islam pada tahun 1930 an dan 40 an yang meliputi beberapa aspek baru iaitu legal, teologi, politik, sosial dan ekonomi yang tercerna dalam pemikiran yang dikategorikan oleh penulis kepada 3 kumpulan iaitu; kumpulan sarjana yang berpendidikan agama atau Arab (tradisionalis) dan ada sebahagian daripada mereka ini dipengaruhi oleh pemikiran reformisme-modenisme Islam dari Timur Tengah yang kelihatannya diwakili oleh penulis-penulis reformis dan pemikirannya di Malaya (Malaysia), b. kumpulan berpendidikan Inggeris yang berminat dengan Islam dan dipengaruhi dengan pembacaan dalam bahasa Inggeris, c. penulis dan pemikir Arab di Singapura, yang mempunyai permasalahan sosial mereka sendiri, yang mana merangsang pemikiran mereka terhadap Islam dan dilahirkan dalam jurnal atau surat khabar Arab mereka. Disertasi ini juga membincangkan pengaruh pemikiran modenis Timur Tengah di Alam Melayu menerusi majalah seperti Al-'Urwa al-Wuthqa dan al-Manar, di mana majalah ini bukan sahaja beredar, tersebar dan mempengaruhi kalangan ulama di bandar atau kota seperti Singapura dan Pulau Pinang tetapi juga sampai ke negeri-negeri yang secara perbandingannya terpencil seperti Kelantan dan Terengganu: "The international link between 'Abd. alWahhab, al-Afghani, 'Abduh and Ridha and some ulama in Malaya was this plausibly established" (Safie 1987: 37).

Fadzillah bin Mohd Jamil (1988), mendalami pembentangan kepada Islam di Malaysia selepas Merdeka, menyentuh kesedaran atau kebangkitan Islam di kalangan 
Muslim dalam dekad 70 an dan 80 an. Penulis mengkaji kegiatan 3 badan dakwah utama Malaysia iaitu ABIM, Darul Arqam dan Jamaah Tabligh. Proses pengislaman dan kesannya ke atas masyarakat Malaysia. Masalah yang merencatkan perkembangan dakwah di Malaysia, pergolakan dan perbezaan dalam parti politik Melayu antara PAS dan UMNO. Termasuk juga ajaran-ajaran sesat dan menyeleweng (hetrodoxy) seperti Taslim, Nasrul haq dan lain-lainnya termasuklah Arqam sendiri, kemudiannya pada Ogos 1994 difatwakan menyeleweng dan sesat oleh Kerajaan (Majlis Fatwa Kebangsaan) dan pertubuhan ini diharamkan. Fokusnya jelas kepada perkembangan dan pergolakan pertubuhan dan gerakan "so called" Islam di Malaysia semasa.

Mohd Kamarulnizam Abdullah Bukhari (1998) dalam kajiannya memeriksa impak sosio-politik daripada fenomena kebangkitan Islam di Malaysia. Bagaimana kerajaan (UMNO) dan parti-parti politik memberi tindakbalas kepada kesan kebangkitan ini dengan menyentuh langsung kesatuan Melayu dan pertembungan masyarakat Melayu. Kajian membincangkan badan-badan dakwah seperti ABIM dan Darul Arqam serta parti politik PAS dan UMNO. Penulis cuba membuktikan bahawa selepas tahun 1980an terdapat tandatanda jelas penggunaan bahasa-bahasa Islam (mesej Islam atau mempolitikkan Islam) dalam politik dan sosial masyarakat Melayu. ABIM serta Darul Arqam yang merupakan pertubuhan bukan politik tetapi kajian ini menunjukkan secara langsung atau tidak langsung terbabit dalam proses politik Malaysia. Manakala UMNO dan PAS menggunakan Islam sebagai platform untuk mendapat sokongan, menambahkan keabsahan, semuanya dikaitkan dengan fenomena dakwah. Penulis juga cuba membuktikan manipulasi agama dalam politik memberi kesan kepada perpecahan di kalangan komuniti Melayu terutamanya di Kelantan, Terengganu, Perlis dan Kedah.

Judith Nagata (1984), membicarakan daripada perspektif antropologi -hubungan Islam dan etnik Melayu, gerakan dakwah dan parti-parti politik Melayu. Nagata telah mengkaji tema-tema dakwah Islam di Semenanjung Tanah Melayu, berusaha memahami bermacam-macam perspektif dakwah, bukan sahaja dari posisi individu Melayu-Muslim tetapi juga program-program yang dilancarkan sama ada oleh badan dakwah Islam atau kerajaan semasa. Analisis lebih kepada hubungan faktor etnik dan agama dalam gerakan dakwah kalangan komuniti Melayu semenjak 1970 an. Penulis mendakwa kemunculan gerakan dakwah di kalangan orang Melayu adalah sebahagian daripada proses untuk memelihara etnisiti, manakala ada sarjana Melayu berhujah dengan menegaskan bahawa banyak institusi telah ditubuhkan dalam usaha memelihara etnik Melayu. Nagata juga menghujahkan politik dan agama telah digunakan sebagai elemen untuk meneruskan kuasa dan kedua-dua faktor tadi ditandakan dengan nama integrasi. Serentak dengan itu simbolsimbol Islam secara meluas digunakan dan terpancar jelas dalam program dan politik kerajaan. Menurut pemerhatian beliau juga, fenomena dakwah Islam ini telah melebarkan jurang atau tanggapan antara Melayu dan bukan Melayu.

Chandra Muzaffar (1987), seorang pemikir Islam dan politik Malaysia semasa, berusaha untuk memahami tabii atau sifat kebangkitan Islam di Malaysia dari perpektif sosiologi. Beliau sependapat dengan Nagata mengemukakan hujah bahawa faktor etnisiti memainkan peranan penting dalam proses kebangkitan Islam. Daripada hipotesis ini, Muzaffar memaparkan fenomena kesedaran Melayu terhadap nilai-nilai Islam. Matlamat analisis Muzaffar ialah memeriksa kenapa kebangkitan Islam berlaku, karakteristiknya, kumpulan yang terlibat dalam proses ini, pendekatan idelogi dan kesannya. Zainah Anwar (1987) mengkaji gerakan dakwah di universiti-universiti di Malaysia, mengenal pasti kumpulan-kumpulan dakwah. Zainah berpendapat berlakunya kompetisasi (pertandingan) di kalangan kumpulan Islam dan kumpulan sosialis, di mana kedua-duanya agak popular di 
kalangan pelajar, namun realiti semasa menunjukkan kalangan Islamis lebih dominan dan memenangi banyak wakil dalam badan-badan perwakilan pelajar di universiti waktu itu.

Muhammad Kamal Hassan (1982) mendiskusi secara serius respons kalangan intelektual Muslim Indonesia terhadap isu modenisasi dan perubahan sosio-politik yang perlu ditangani oleh masyarakat. Pendapat Deliar Neor, Nurcholish Madjid dan Sidi Gazalba menunjukkan berlakunya dilema politik dan intelektual antara tokoh-tokoh di atas merujuk kepada pembangunan masyarakat Islam yang diingini. Di mana kalangan akomodasionis politik Muslim (pecahan kumpulan modenis) seperti Nurcholish Madjid menganggap, Islam secara esensialnya agama personal (seperti pandangan tokoh masyhur Mesir Ali Abdul Raziq dalam bukunya al-Islam wa usul al-hukm yang mengatakan, Islam tidak berhasrat untuk diaplikasikan kepada politik), jadi sekularisasi diperlukan bagi pemodenan Indonesia. Diikuti kemudiannya analisis dan jawapan yang menilai dan menolak pandangan di atas.

Begitu juga buku Deliar Neor (1973), memperincikan asal-usul dan perkembangan gerakan moden Muslim di Indonesia yang meliputi bidang-bidang pendidikan, sosial dan politik. Dikemukakan juga reaksi daripada pemerintahan Belanda, tradisionalis dan nasionalis Muslim Indonesia. Buku ini juga mencatatkan secara ringkas pengaruh reformis Muslim Timur Tengah ke atas gerakan modenis di Indonesia dan tabii gerakan tersebut.

Kategori ketiganya karya dan penerbitan yang membincangkan pemikiran politik Islam; sama ada bersifat umum atau menyentuh Malaysia-Indonesia. Antaranya tesis peringkat doktor falsafah, Sidek Fadzil (1989) membincangkan bagaimana berlakunya pertembungan tamadun Barat dengan Islam dan penyerapan tamadun itu. Berlakunya proses pembaratan dalam Dunia Melayu sehingga mewujudkan kelompok elit Melayu pengkagum Barat. Ideologi Barat seperti nasionalisme, sekularisme, kapitalisme, sosialisme dan demokrasi memberikan cabaran baru kepada dunia Islam dan Alam Melayu. Tesis ini walau bagaimanapun mengupas secara khusus isu nasionalisme dan sekularisme sahaja. Apakah nasionalisme Barat dapat didamaikan dengan Islam atau tidak, apakah penyelesaian-penyelesaian yang diperlukan agar dapat diterima oleh Islam, apakah bentuk negara yang harus diaspirasikan - negara Islam atau negara nasional.

Selanjutnya tesis doktor falsafah Jaffary Awang (2000). Kajian ini cuba mengenal pasti persoalan epistemologikal, filosofikal, fondasi teoritikal, prinsip dan orientasi kebangkitan Islam kontemporari Malaysia. Kupasan pandangan tokoh-tokoh seperti Syed Muhammad Naguib al-Attas, Mustafa Kamal Hassan dan Anwar Ibrahim serta pertubuhan bukan kerajaan dan parti politik seperti UMNO, PAS dan ABIM menyentuh sekularisme, pendidikan Islam, dan identiti Muslim serta secara khusus tentang konsep ummah (bangsa).

Akram Raslan Deiranieh (1976) dalam disertasinya memeriksa konsep negara Islam klasik pada tahun-tahun awal pembentukannya di Zaman Rasulullah s.a.w. dan Khulafa` alRashidin dengan niat mengenal pasti elemen-elemen kunci politikal yang dianggap prinsip asas negara dan kerajaan dalam Islam. Penubuhan negara Islam dikaji berdasarkan 3 elemen asas iaitu; rakyat, wilayah, dan organisasi politik. Dan dari segi tabii atau sifat dan skop autoriti politiknya berakar kukuh pada doktrin teologi uniti dari Al-Qur`an, kesatuan Tuhan, kesatuan undang-undang dan kesatuan manusia. Dan dalam pegamalan praktikalnya, konsep uniti Islam dimantapkan pada 3 prinsip kehidupan berpolitik iaitu keadilan, ketaatan dan shura. Pengkaji tersebut memetik pandangan Sayyid Qutb: "Political authority in Islam, following the acceptance of God's unity and His sovereignty, is based on just conduct of the rulers, the obedience of the ruled, and consultation between the ruler and the ruled".

Memang masih banyak tulisan-tulisan ahli akademik mengenai perkembanganperkembangan kontemporari di dunia Islam, memfokuskan pada hubungan antara Islam 
dan politik. Salah satu karya yang tergolong dalam kategori ini adalah kajian Rosenthal pada tahun 1965, Islam in the modern nation state. Meskipun ianya ditulis dalam masa yang sudah agak lama tetapi ia merupakan karya yang penting disebabkan ada menulis tentang Islam dan politik Melayu. Selanjutnya dalam semangat yang sama tetapi agak terkini ialah tulisan Nazih Ayubi (1991) Political Islam, sangat meyakinkan dalam menyoroti perkembangan di dunia Arab, serta memberi perhatian yang baik kepada idea-idea para intelektual Islam, termasuklah intelektual-intelektual liberal yang menentang kaitan Islam dengn politik-kepartian. Dan akhirnya Ozau Mehmet (1990) Islamic identity and development, sebuah buku perbandingan perkembangan Islam dan identitinya antara Malaysia dan Turki.

Kajian pula ini mempunyai kelainan daripada kajian-kajian lepas yang telah disebutkan di atas dalam beberapa aspek dan pendekatan, Pertamanya, fokus kajian terarah kepada perkembangan urutan dan rantaian modenis Malaysia dan tabiinya, pada zaman kontemporari kini, walaupun telah ada kajian tentangan modenisme di Malaya pada tahun 1930 an dan 40 an yang khusus kepada tokoh Syeikh Syeikh al-Hadi. Keduanya, perbahasan tentang suasana tidak kondusif dan memangkin bagi perkembangan aliran modenisme, sehingga idea-idea dan pemikiran mereka tidak menadapat sambutan. Jadi senario ini juga memerlukan pemaparan yang khusus dan pengkaji merasakan, studi khusus perkara ini, sepanjang pengetahuan pengkaji masih belum ada. Ketiganya, sewaktu menelaah bukubuku tentang aliran modenisme di Malaysia, pengkaji merasakan wujudnya perbezaan kriteria, sifat dan persepsi tokoh-tokoh Malaysia tentang modenisme dari rakan-rakan mereka di luar negara. Justeru itu juga diperlukan pendefinisian modenisme khusus dalam konteks Malaysia. Akhirnya pandangan dan pentafsiran khusus tokoh-tokoh modenis semasa tentang beberapa isu yang menjadi pilihan seperti konsep negara Islam, dan nasionalisme serta hubungan secara tidak langsung dengan sekularisme.

Kesimpulannya artikel ini menghurai dan mewacanakan tranfsformasi pemikiran perubahan dan pembaharuan (modenisme) di dunia Islam secara umum dan dalam konteks Malaysia secara khusus dengan fokus kepada parti politik Melayu-Islam, UMNO dan PAS. Tulisan ini merupakan pengubahsuaian proposal pengkaji bagi tesis doktor falsafahnya. Kajian dimulai dengan perbincangan konsep modenisme, ciri, sejarah dan perkembangannya secara umum di dunia Islam, kemudian diikuti dengan kawasan Nusantara dan Malaysia lebih khususnya. Analisis dan dapatan kajian membuktikan bahawa proses pembaharuan yang berlaku di Malaysia memiliki bentuk, sifat dan corak tersendiri yang dalam hal-hal tertentu berbeza dari apa yang berlaku di tempat lain di dunia Islam. Inilah yang dinamakan manhaj Malaziyy atau ala-Malaysia seperti yang berlaku dalam bidang politik dengan konsep perkongsian kuasanya (power sharing) dengan kaum, bangsa dan agama lain berpandukan komposisi bangsa di Malaysia.

\section{References}

Abu Bakar Hamzah. 1991. Al-Imam: Its Role in Malay Society 1906-1908. Kuala Lumpur: Pustaka Antara.

Adams, C. 1968. Islam and Modernism in Egypt. New York: Russell \& Russell.

Ahmad Amir Aziz. 1999. Neo-Modernisme Islam di Indonesia: Gagasan Sentral Nurcholish Madjid dan Abdurrahman Wahid. Jakarta: PT Rineka Cipta.

Akhbar S. Ahmed. 1988. Discovering Islam: Making Sense of Muslim History and Society. London: Routledge.

Alatas, S.H. 1972. Modernization and Social Change. Sydney: Angus and Robertson Publisher. 
Barton, G. 1999. Gagasan Islam Liberal di Indonesia: Pemikiran Neo-Modernisme Nurcholish Madjid, Djohan Effendi, Ahmad Wahib, dan Abdurrahman Wahid 1968-1980, Transl. Nanang Tahqiq. Jakarta: Paramadina.

Benard, C. 2003. Civil Democratic Islam: Partners, Resources and Strategies. California: Rand Corporation.

Burhanuddin Daya. 1990. Gerakan Pembaharuan Pemikiran Islam: Kasus Sumatera Thawalib. Yogyakarta: Tiara Wacana Yogya.

Chandra Muzaffar. 1987. The Islamic Resurgence in Malaysia. Petaling Jaya: Penerbit Fajar Bakti.

Dessouki, Ali E. Hillal 1982. The Islamic Resurgence: Sources, Dynamics and Implications. New York: Praeger Publishers.

Deliar Neor. 1973. The Muslim Modernist Movement in Indonesia 1900-1942. Kuala Lumpur: Oxford University Press.

Deiranieh, Akram Raslan. 1976. The classical concept of state in Islam. Tesis Ph.D. University of Chicago.

Dobbin, C. 1983. Islamic Revivalism in a Changing Peasant Economy: Central Sumatera 17841847. London: Curzon Press.

Esposito, J.L. 1984. Islam and Politics. Syracuse: University Press.

Fadzillah Mohd Jamil. 1988. The reawakening of Islamic consciousness in Malaysia 19701987. Tesis Ph.D. University of Edinburgh.

Federspiel, H. M. 1970. Persatuan Islam: Islamic Reform in Twentieth Century Indonesia. Ithaca: Cornell University.

Gordon, A. (ed.) 1999. The Real Cry of Syed Shaykh al-Hady. Kuala Lumpur: MSRI.

Ginsburg, N \& Roberts, C. F. 1958. Malaya. Seattle: University of Washington Press.

Haddad, Y.Y. 1986. Muslim revivalist thought in the Arab world, The Muslim World, 76 (2).

Hall, J. W. Changing conceptions of the modernization of Japan, Dlm. Marius B. Jansen (ed.). 1965. Changing Japanese Attitudes toward Modernization. Princeton: Princeton University Press.

Ibrahim Abu Bakar. 1994. Islamic Modernism in Malaya: The Life and Thought Sayid Syekh Al-Hadi 1867-1934. Kuala Lumpur: Universiti Malaya Press.

Jaafary Awang. 2000. Notions of Ummah in Islam: the Response of Malay Muslim Intellectual in Malaysia. Tesis Ph.D. University of Birmingham.

Mazheruddin Siddiqui. 1982. Modern Reformist Thought in the Muslim World. Islamabad: Research Institute.

Mohd. Rumaizuddin Ghazali. 2005. Bicara Haraki: Aliran-aliran pemikiran Islam di Malaysia, http://www.abim.org.my/minda_madani/modules.php.

Mohd Kamarulnizam Abdullah Bukhari. 1998. The socio-political implication of the dakwah phenomenon (Islamic revivalism) in Malaysia: questions of Malay unity and national security. Tesis Ph.D. University of Lancaster.

Mohd. Sarim Mustajab. 1979. Gerakan Islah Islamiyyah di Tanah Melayu 1906-1948. Dlm. Malaysia: Sejarah dan Proses Pembangunan. Kuala Lumpur: Percetakan United Selangor.

Mohamad Abu Bakar 1987. Penghayatan Sebuah Ideal: Suatu Tafsiran tentang Islam Semasa. Kuala Lumpur: Dewan Bahasa dan Pustaka.

Mohamad Abu Bakar. 1994. Pemikiran Islam: Akar, Aliran dan Arah, Kertas Kerja Seminar Pemikiran Islam dan Cabaran Semasa Peringkat Kebangsaan. UTM, K. Lumpur. 2324 April.

Muhammad Kamal Hasan. 1982. Muslim Intellectual Responses to "New Order" Modernization in Indonesia. Kuala Lumpur: Dewan Bahasa dan Pustaka. 
Pendeta Paulus D.H. Daun. 1987. Apakah Liberalisme dan Modernisme ?Yogyakarta: Yayasan Andi.

Nagata, J. 1984. The Reflowering of Malaysian Islam: Modern Religious Radicals and Their Roots. Vancouver: University of British Columbia Press.

al-Qardhawi (ed.). 1998. Kebangkitan Islam: dalam Perbincangan Para Pakar. Transl. Moh. Nurakma. Jakarta: Gema Insani Press.

Raden Soenarno. 1960. Malay nationalism 1896-1941. Journal of Southeast Asian History 1:1, March.

Roff, W.R. 1967. The Origins of Malay Nationalism. Kuala Lumpur: University of Malaya Press.

Roff, W.R. 1962. Kaum Muda-Kaum Tua: innovation and reaction amongst the Malays 19001941 dlm. K.G. Tregonning (pnyt.). Papers on Malayan History. Singapore: University Malaya Press.

Roff, W.R. 1967. The Origins of Malay Nationalism. Kuala Lumpur: UM Press.

Safei Ibrahim. 1987. Islamic religious thought in Malaya 1930-1940. Tesis Ph.D. Columbia University.

Sidek Fadzil. 1989. Pemikiran Barat moden: sikap para cendekiawan Muslim dengan tumpuan di Alam Melayu. Tesis Ph.D. Institut Alam dan Tamadun Melayu. Universiti Kebangsaan Malaysia.

Sidney, R.J.H. 1926. Malay Land "Tanah Melayu": Some Phases of Life in Modern British Malaya. London: Cecil Palmer.

al-Sufi, Abd. al-Qadir. 1979. Resurgent Islam 1400 Hijra. Norwich: Diwan Press.

Thompson, V. 1943. Postmortem on Malaya. New York: The Macmillan Company.

Zainah Anwar. 1987. Islamic Revivalism: Dakwah among Students. Kuala Lumpur: Pelanduk Publications. 